\title{
Att återvända till fäderneslandet - hur den nubiska drömmen kan bli en rättighet $i$ det nya Egypten
}

\author{
"These are all my pages; do not tear them up \\ This is my voice; do not silence it \\ This is I; do not curse me \\ For I have lived among you and eaten with you, \\ loved your culture, and still do. I am merely \\ conveying to you, with the sting of truth, some of \\ my sorrows, and those of my people.»
}

Av Maja Janmyr, postdoktor ved Det juridiske fakultet, Universitetet i Bergen

$\mathrm{D}$ ETTA ÄR RADER UR IDRIS ALIS DONGOLAS A Novel of Nubia; "kulturen» som Ali refererar till, är norra Egyptens arab-egyptiska kultur, och "folket» med vilka författaren identifierar sig och vars "sorger» han delar, är nubierna från södra Egypten. ${ }^{1}$ Det etniskt distinkta nubiska folket härstammar från en civilisation lika gammal som det forna Egypten, och har under tusentals år befolkat Nilens flodbankar i ett område som sträcker sig från Assuan i södra Egypten och ända in i norra Sudan. Här har de hållit fast vid en egen kultur, egna seder och sitt eget språk. Efter att det nubiska folket först blivit godtyckligt fördelade mellan Sudan och Egypten 1899, blev Egyptens nubier tvingade på flykt när byggandet av en rad dammar resulterade i översvämningen av de nubiska landområdena under 1900-talet. ${ }^{2}$ Det mest omfattande av dessa byggen skedde på det sena 1950- och tidiga 1960-talet då dåvarande president Gamal Abdel Nasser initierade konstruktionen av Assuandammen i ett försök att modernisera Egypten.

Uppemot 50 ooo egyptiska nubier tvångsförflyttades till så kallade «vidarebosättningsbyar», primärt kring Kom Ombo, ca 50 km norr om staden Assuan. Få nubier var tillfreds med den nya lösningen, framför allt för att de nya hemmen var belägna långt ifrån Nilen. Svårigheterna som mötte dem som tvångsförflyttats var omfattande och är väldokumenterade. ${ }^{3}$ I väntan på att de utlovade nya, moderna husen skulle bli byggda slog nubiska familjer sig ned också på andra håll i Egypten. ${ }^{4}$ För många tycks denna väntan ha blivit permanent.

Situationen för det nubiska folket i Egypten 


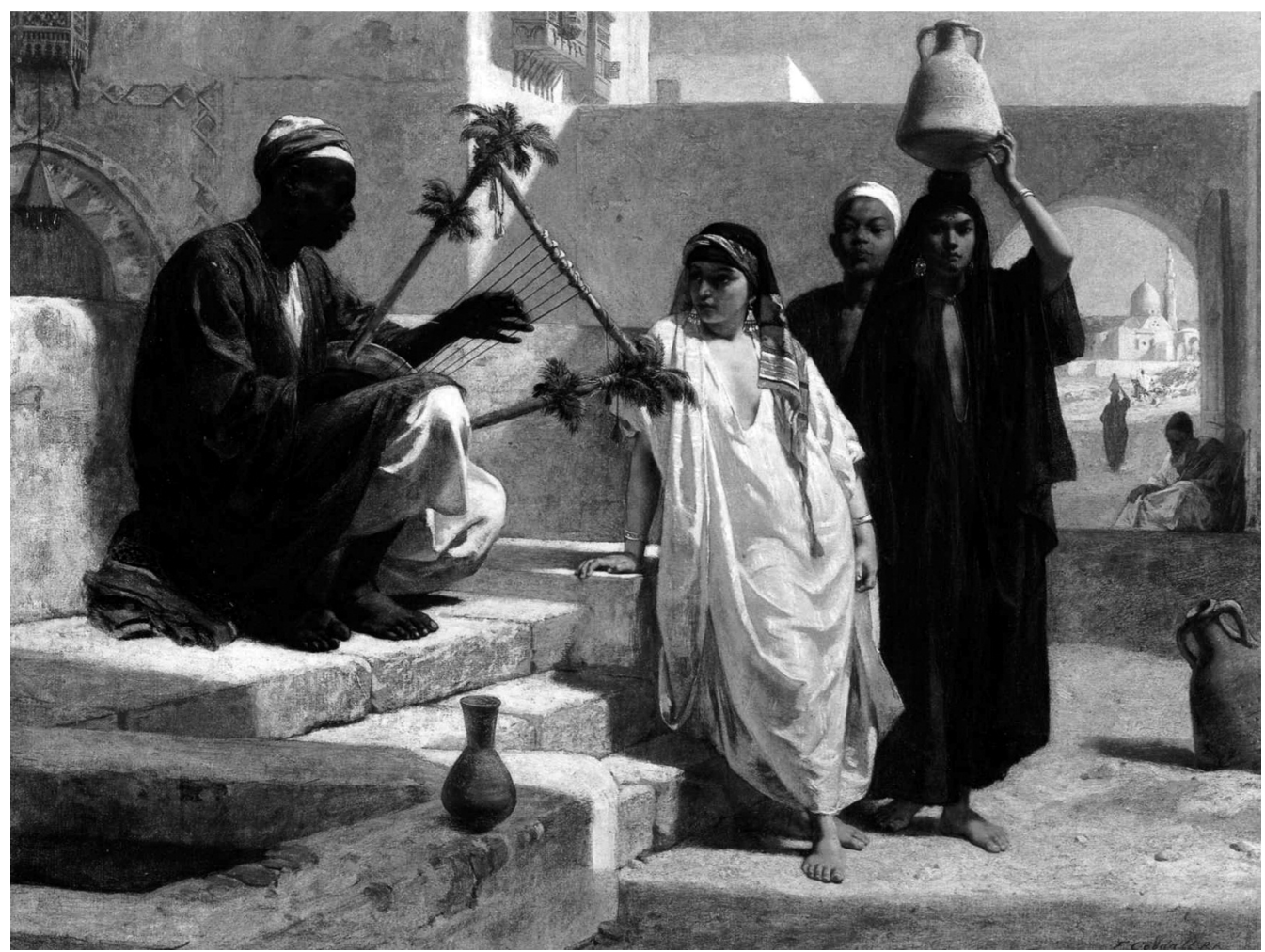

Frederick Goodall: «The song of the Nubian slave» (1852).

har försvårats av att staten sedan länge har förnekat att urfolk och etniska minoriteter ens existerar i landet. ${ }^{5}$ Dess tonvikt på det egyptiska folkets språkliga, kulturella och etniska homogenitet har marginaliserat nubierna som grupp, och försök att mobilisera för att kräva ökade rättigheter har slagits ned brutalt. Trots de uppenbara riskerna har dock nubiska aktivister blivit allt mer högröstade i sina krav på förändring under det senaste decenniet. Jag vill här utforska en aspekt av den utvecklingen, nämligen hur nubiska aktivister mobiliserade för att få återvända till fäderneslandet. Hur föregick en sådan rättighetsmobilisering i en nationalistisk och repressiv miljö som den egyptiska? Vad, mer konkret, lyckades aktivisterna åstadkomma? Jag vill hävda att nubiska aktivisters mobilisering för ett återvändande påskyndades under den egyptiska revolutionen 2011 och kulminerade i omnämnandet av ett nubiskt återvändande i 2014 års egyptiska konstitution.

Egyptens nubier är ingen homogen grupp; nubierna skiljer sig åt på flera olika sätt. De har bosatt sig både utanför och innanför Egyptens landgränser, i större städer och i fler än femtio nubiska byar, varav de flesta inte återfinns på sina ursprungliga platser. Vissa självidentifierar sig inte alls som nubier, utan som egyptier, egyptisk-nubiska eller genom andra former av självidentifikation. Då det är närmast omöjligt att redogöra till fullo för denna varierande grupp kommer den här artikeln att fokusera på de nubiska aktivister som har mobiliserat för ett återvändande med utgångspunkt i en delaktighet i ett nubiskt kollektiv. Artikeln base- 
ras på fältarbete och arkivstudier i Kairo mellan mars och maj 2014, samt i februari 2015. Semi-strukturerade intervjuer genomfördes i Kairo och via Skype med nubiska aktivister inom de aktivistgrupperna som har varit ledande i mobiliseringen för ett nubiskt återvändande. Artikeln baseras också på en analys av publicerade och icke-publicerade rättsliga dokument, inklusive framställanden till FN och lagförslag gällande ett nubiskt återvändande, samt Nubia-relaterade mediepublikationer och nubiska grupper på sociala medier.

För att förklara denna mobilisering använder jag de verktyg och begrepp som återfinns inom rättsmobiliseringsstudier (legal mobilization studies). Sådan rättsmobilisering syftar till att uppnå social förändring genom rättsnormer eller diskurser, och innebär inte bara rättsprocesser utan även aktivism. ${ }^{6}$ Mest intressant i vårt fall är det som kallas legal framing, som inte bara innebär domstolsprocesser, utan också en rättsnarrativ infallsvinkel. ${ }^{7}$ En frame kan översättas med en tolkningsram och handlar om den förståelse av en given situation som rörelserna själva har, samt hur deras handlingar alltid inbegriper en aktiv omtolkning av denna förståelse.$^{8}$ Cenom en bred social-konstruktionistisk syn kan vi alltså bättre förstå hur rätten hjälper till att skapa mening och identitet i människors dagliga liv.

För att på bästa sätt förstå den kontext som nubiska aktivister verkar inom, så börjar denna artikel med att förklara den egyptiskarabiska nationalismen och dess inverkan på en statlig marginalisering och förtryck av det nubiska folket. Därefter följer en genomgång av de viktigaste nubiska grupperna som uppstod under en serie av nationella kriser i slutet av 2000-talet, och förstärktes under och efter den egyptiska revolutionen 2011. Jag förklarar även hur den första post-revolutionära tiden under president Mohamed Morsi innebar en förstärkning av den nubiska indignationen, då många ansåg att Morsis styre bara var en fortsättning på tidigare president Mubaraks strategier för att ha kontroll över nubierna. Slutligen beskriver jag hur den konstitutionella processen som följde den egyptiska arméns avsättning av Morsi juli 2013 innebar ett tidigare oskådat nubiskt deltagande. Detta resulterade framför allt $i$ ett omnämnande av ett nubiskt återvändande i 2014 års grundlag. Slutligen diskuterar jag huruvida denna konstitutionella bestämmelse kommer att kunna implementeras, och lyfter fram en rad faktorer som kan påverka detta.

\section{Nationalism, marginalisering och förtryck}

Trots att den omfattande tvångsförflyttningen av det nubiska folket under 196o-talet bidrog till ökad politisk, social och ekonomisk marginalisering, så uteblev omfattande politisk och social oro bland nubierna. Få försök gjordes för att bryta marginaliseringen och någon större mobilisering har inte genomförts förrän nu, under det senaste decenniet. Vad beror detta på? Ett allmänt lågt stöd för social mobilisering för demokratiska reformer i Egypten kan till viss del förklara passiviteten, ${ }^{9}$ men det finns även andra omständigheter som tycks ha spelat in. Den egyptisk-arabiska nationalismen och den egyptiska statens marginalisering och förtryck av det nubiska folket tycks i sig ha haft en stor påverkan på folkets möjligheter att mobilisera för ökade rättigheter och politisk förändring.

Trots att Egypten röstade för FN:s tre deklarationer rörande minoritetsrättigheter (1992), kulturell mångfald (2001) och om urfolkens rättigheter (2007), har den egyptiska staten på hemmaplan fokuserat på att homogenisera den egyptiska befolkningen och befästa en allmän nationell identitet. Vi ser ett tydligt exempel på detta i den egyptiska konstitutio- 
nen från 1971, där artikel 1 fastslår att «det egyptiska folket är en del av den arabiska nationen och arbetar för dess fullkomliga enhet. $»^{10}$ Minoritets- och urfolksrättigheter har sedan länge varit tabu och rättigheter har därmed endast getts mot bakgrund av medborgarskap. ${ }^{11}$ Frånvaron av formella avgränsningar mellan exempelvis nubier och andra egyptier har legat i hjärtat av den egyptisk-arabiska nationalismen och det är därför i princip omöjligt att fastslå antalet nubier i Egypten. Denna osäkerhet kan förklara varför nubiska aktivisters beräkningar av antalet nubier i dagens Egypten varierar kraftigt och ligger på allt ifrån 300000 till 3 miljoner individer. ${ }^{12}$

Som anhängare av den egyptisk-arabiska nationalismen, tycks många nubier dessutom ha stöttat konstruktionen av Assuandammen; de nubiska hemmen ansågs vid tillfället av många nubier att offras just för «den större

\section{Den egyptiska staten har fokuserat på att homogenisera den egyptiske befolkningen och befästa en allmän nationell identitet. e}

egyptiska samhällsnyttan». ${ }^{13}$ President Nasser hade skickligt lyft in frågan om tvångsförflyttning i den till synes neutrala kontext för «nationell utveckling», vilket säkerligen stävjade den sociala och politiska oro som annars hade kunnat följa en sådan förflyttning. Ett ifrågasättande av tvångsförflyttningen hade kunnat uppfattas som illojalitet mot det nationalistiska projektet, vilket tycks ha bidragit till att många nubier istället valde att vänta tålmodigt på att staten skulle ta itu med deras situation. Trots upprepade löften hade över 5000 nubiska familjer 2010 ännu inte kompenserats för sina exproprierade hem. ${ }^{14}$
Den egyptiska nationalismen innebar vidare antagandet av en arabiseringspolitik som förespråkade det arabiska språket och stigmatiserade andra dialekter och kulturer som bakvända och splittrande. Vissa menar att denna nationalism, istället för att vara anti-imperialistisk, anti-rasistisk och revolutionär, faktiskt förstärkte historiska och rasrelaterade strukturer av förtryck där fördomar mot nubier länge varit ett utmärkande drag. ${ }^{15}$ Idag upplever nubiska aktivister också en process som de kallar «av-nubianisering», vilket bland annat innebär bosättandet av arabiska grupper på det landområde som nubier anser sig ha rätt till, samt att nubier tvingas följa en strikt egyptiskarabisk läroplan i skolan på bekostnad av nubiska språk och kultur. ${ }^{16}$ Mycket riktigt framhävs arabiska som det enda statliga språket $\mathrm{i}$ 1971 års egyptiska konstitution och det har alltid varit omöjligt att lära sig de nubiska språken inom det egyptiska skolsystemet.

Tidigare studier har pekat på att mobilisering är mer kostbart för de fattiga och maktlösa. ${ }^{17}$ En stor andel av Egyptens nubier har okvalificerade arbeten, något som också speglas i egyptiska filmer och annan media, där nubier ofta framställs som dörrvakter, tjänare och chaufförer. ${ }^{18}$ Marginalisering och diskriminering av nubier i Egypten anses vara så omfattande att Internationella arbetsorganisationen (ILO) har slagit fast att nubierna «behandlas generellt inte som likvärdiga medlemmar av samhället». ${ }^{19}$ Urfolk i Egypten anses på det hela taget vara de minst politiskt representerade och mobiliserade i det egyptiska samhället, och de saknar institutioner som förespråkar deras rättigheter eller säkrar deras rätt att yttra sig i frågor som rör dem.

Även om ett väldigt begränsat främjande av nubisk kultur har tillåtits, har allt stöd för förekomsten av en separat grupp med eget språk och historia tolkats som ett hot mot landets sä- 
kerhet. ${ }^{20}$ Således har många nubier — även om de flesta anser sig vara egyptier fullt ut —ofta fått bemöta påståenden om att de skulle vara separatister, och nubiska organisationer har varit måna om att vara icke-kontroversiella och icke-politiska. ${ }^{21}$ De välkända "nubiska klubbarna», som bildades runtom i Egypten efter tvångsförflyttningen för att erbjuda nubiska familjer en gemensam mötesplats, har exempelvis aldrig arbetat bredare för nubiska rättigheter. Eftersom politisk mobilisering har mötts av misstro och förtryck har nubierna som grupp i stort sett varit icke-politiska de senaste femtio åren. ${ }^{22}$

\section{Kris och revolution}

Nubiska aktivister har länge varit väl medvetna om de risker som det innebär att kräva rättigheter från staten, och för gemene nubier var sådan mobilisering under lång tid alltför riskabelt. Det senaste decenniet började dock ett ökande antal nubier uppleva status quo som ett än större hot mot det nubiska folkets existens. Det politiska landskapet förändrades också drastiskt med början i ett ökande antal proteströrelser som krävde ett slut på Egypten som enpartistat. ${ }^{23}$ Denna utveckling innebär att vi på senare år har kunnat se en nubisk rättighetsmobilisering $i$ en tidigare aldrig skådad skala.

I mitten av 2000-talet bildades flera föreningar som kom att spela en betydande roll när det gäller att lyfta fram frågan och mobilisera för nubiers rättigheter i Egypten. En av dessa är det Egyptiska centret för rätten till bostad (ECHR), som stiftades för att arbeta brett med alla egyptiers sociala- och ekonomiska rättigheter. Kort tid efter att centret etablerades fick det in en mängd ärenden gällande nubiernas boendesituation. Eftersom ECHR:s ledare, Manal el-Tibi, själv hade nubiskt påbrå och precis hade skrivit sitt examensarbete vid Ame- rican University in Cairo om just nubiers rättigheter som urfolk, lyftes frågan om nubiers rätt till återvändande snart som en av ECHR:s hjärtefrågor. ECHR var tidigt ute med att koppla frågan om nubiernas boendesituation till det bredare internationella rättsliga ramverket som omhandlar urfolkens rättigheter. Exempelvis organiserades konferensen «Nubia between Resettlement and Development» i Assuan i april 2007 där ECHR försökte få det nubiska folkets medgivande att ta upp «den nubiska frågan" hos FN:s högkommissarie för mänskliga rättigheter när denne skulle genomföra sin allmänna återkommande utvärdering (UPR) av Egypten. ${ }^{24}$ Egyptiska myndigheter försökte först stoppa konferensen av säkerhetsskäl, men gav med sig då EcHr hotade att flytta den utomlands. Ytterligare internationell fokus på nubiernas situation var det sista som myndigheterna önskade sig. ECHR fick till slut in sin skrivelse till $\mathrm{FN}$, något som var ett tidigare oskådat och djärvt utspel.

Ytterligare en central förening som beredde vägen för en bredare nubisk rörelse är den Egyptisk-nubiska juristföreningen (ENAL), som bildades 2009 av juristen Mounir Bashir. Redan 2007 hade Bashir försökt att registrera sin förening men fick avslag på grund av det stora fokuset på nubiska folkets rättigheter. ${ }^{25}$ Det var för först efter att han breddade ENALS kärnverksamhet till att omfatta alla egyptiers rättigheter som han fick tillstånd. ENAL har drivit flera rättsprocesser gällande expropriering av nubiska hem och kompensation för förlorad egendom; egyptiska domstolar har dock dröjt i sitt hanterande av dessa fall och de flesta har därför fortfarande inte avgjorts än idag. ENAL har även arbetat fram flera lagförslag gällande ett omfattande nubisk återvändande, och dessa har visat sig bli oerhört betydelsefulla för den post-revolutionära nubiska rörelsen. 
Ungefär samtidigt som ENAL och ECHR bildades, så formades också de så kallade Uppföljningskommittéerna i Kairo, Alexandria och Aswan. Dessa har framför allt förhandlat informellt med egyptiska myndigheter och har varit inflytelserika när det gäller att få fram finansiering för att bygga fler nubiska bostäder. Till skillnad från ENAL Och ECHR har kommittéerna dock hållit sig undan frågor om mänskliga rättigheter, även om de kom att spela en viktig roll i implementeringen av 2014 års egyptiska konstitution.

Föreningar som de jag nämnde ovan var alltså viktiga för att lägga grunden för en bredare mobilisering. De bidrog med resurser, framförallt i form av kunskap, vilket gjorde att det fanns en etablerad grund, varifrån nubisk rättighetsmobilisering kunde ta form när de politiska möjligheterna väl öppnade sig. Och det gjorde de: upptakten för nubisk aktivism återfinns i nationella kriser, exempelvis den så kallade Brödkrisen april 2008. En stor generalstrejk utbröt som ett gensvar på låga löner och ökade matkostnader, och denna kris skiljde sig från tidigare protester genom att den innebar omfattande användning av sociala medier, vilket underlättade organiserandet av strejker, protester och demonstrationer runtom i landet. För den nubiska ungdomsgenerationen skapade Brödkrisen ett politisk momentum, och inte minst inspiration till mobilisering för att kräva specifika rättigheter för det nubiska folket. Dessa ungdomsaktivister, varav många aldrig ens har besökt det som omtalas som "Camla Nubia», blev snabbt de mest högröstade och politiskt engagerade bland det nubiska folket och de tog avstånd från vad de ansåg vara tidigare generationers passivitet gentemot den egyptiska staten. Ett exempel på en förening som etablerades under denna tid är den Nubiska demokratiska ungdomsunionen (NDYU), som bildades av nubiska universitets- studenter 2009 för att «försvara nubiska folkets rättigheter och minoritetsgrupper i Egypten. $»^{26}$ Ungdomsorganisationer som detta har framför allt mobiliserat stöd för sina krav genom sociala medier.

25-januari-revolutionen, där egyptiska folket 2011 protesterade mot, och sedan stjälpte Mubarak-regimen, framskyndade markant den nubiska rättighetsrörelse som hade fötts några år tidigare. Före dess hade nubierna som kollektiv inte gått ut på gatorna för att kräva sina rättigheter, men nu deltog många i protesterna mot regimen. Intervjuer med ungdomsaktivister antyder att många nubier inte mobiliserade för att de nödvändigtvis ansåg att de tog färre risker än tidigare, utan för att många ansåg att detta var den bästa möjligheten hittills att agera. ${ }^{27}$ De flesta som deltog i revolutionen gjorde det som både egyptier och nubier, inte antingen eller, men revolutionen innebar en möjlighet för många unga nubier att uttrycka en "organiserad ilska» mot regeringen som de ansåg brast i sin plikt att erkänna och försvara nubiska rättigheter. ${ }^{28}$

I kölvattnet av revolutionen handlade flera av de nubiska protesterna, särskilt de i Assuan, uttryckligen om nubiska särkrav, däribland rätten att återvända till fäderneslandet. Nubiska aktivister var också snabba att mobilisera mer organiserat, exempelvis genom att anordna konferensen «The Problem of Nubian Rights Before and After the January 25 Revolution». Det politiska klimatet i post-revolutionära Egypten gav också nubiska ungdomsaktivister möjlighet att internationalisera sin kamp. Ungdomsgrupper som NDYU deltog i flera internationella konferenser, däribland workshopen «Citizenship Spring» i november 2011, där Svenska Institutet i Alexandria var medarrangör. Även om de flesta aktivister pratar om sådana nätverksmöjligheter som oerhört viktiga i etablerandet av relationer med 
andra aktivistgrupper både i och utanför Egypten, har internationaliseringen inte varit helt enkel. ECHR och el-Tibi fick redan 2010 motstå kraftiga anklagelser om ett stundande nubiskt utträde när de lämnade in skrivelsen till FN om nubiska folkets situation i Egypten, i vilken de bl.a. uppmanade FN att officiellt erkänna Egyptens nubier som urfolk. Denna «mycket riskabla» politiska situation tvingade ECHR att avstå från att lämna in ytterligare skrivelser inför FNS 2014 UPR av Egypten. ${ }^{29}$ Inför risken att framstå som separatister, har de nubiska aktivisterna i Egypten få formella band till liknande nubiska rörelser i grannlandet Sudan. Många nubiska aktivister upplever än idag hotelser och förföljelse, och ibland även fysiska angrepp och svårigheter att delta i rättsprocedurer. ${ }^{30}$

\section{Indignation och fragmentering}

I början av 2012 röstades ett nytt post-revolutionärt parlament fram. Det nya parlamentet bestod huvudsakligen av en islamist-koalition dominerad av Muslimska brödraskapet, och nubier som grupp var inte representerade trots den ökande uppmärksamheten kring deras situation..$^{31}$ Vid denna tidpunkt hade ENAL arbetat fram två lagförslag. Det ena skulle garantera ett nubiskt återvändande till fäderneslandet och den andra etablerade en så kallad Högnivåkommitté för utveckling som skulle säkra nubiska folkets intressen vid ett återvändande. ${ }^{32}$ Dessa lagförslag presenterades $\mathrm{nu}$ för parlamentet och samtidigt hölls flera högnivåmöten mellan regeringstjänstemän och representanter för det nubiska folket. ${ }^{33}$ När dessa initiativ inte ledde någonstans kände många nubier att deras krav återigen hade blivit åsidosatta. ${ }^{34}$ En förvärrande omständighet var att nubier som grupp också exkluderades från den konstitutionella församling som hade bildats för att arbeta fram Egyptens första post- revolutionära konstitution. Även den dominerades av islamistiska partier. Manal el-Tibi från ECHR hade valts in $i$ församlingen för egen räkning, men avgick i september 2012 i protest mot den "motrevolution» som hon ansåg att den icke-representativa församlingen drev. ${ }^{35}$ Trots flera försök att reformera församlingen blev den slutliga konstitutionen snabbt hårt kritiserad för bristen på grundläggande fri- och rättigheter.

När Mohamed Morsi tillträdde som president juni 2012 förstärktes den nubiska indignationen, då många ansåg att Morsis styre bara var en fortsättning på Mubaraks strategier för kontroll över nubierna. ${ }^{36}$ Under upptakten till själva presidentvalet hade också en framträdande medlem av det Muslimska brödraskapet, Morsis eget parti, i en vida cirkulerad debattartikel beskrivit det nubiska folket som en av Egyptens kolonisatörer. ${ }^{37}$ Nubiska aktivister tog nu till gatorna i protest mot den nya regimen - exempelvis deltog inte mindre än 60 nubiska föreningar i protester utanför det egyptiska parlamentet januari 2013 och krävde ett slut på marginaliseringen och möjlighet att få återvända till fäderneslandet. ${ }^{38}$

$\mathrm{Nu}$ hade den nubiska rörelsen växt sig stark men var ännu fragmenterad och även polariserad, särskilt genom splittringar mellan generationerna, då nubiska ungdomsgrupper anklagade äldre generationer för att tidigare ha svikit det nubiska folket när de inte gick hårdare fram för sina krav. Därtill kom en ökad inblandning från delar av den nubiska diasporan och uppkomsten av en till synes väpnad Katala («modig krigare»)-rörelse. Den sistnämnda blev till i november 2012 och hade som uttalat mål att genom våld återta nubiska rättigheter och separera Nubia helt från Egypten om inte nubiska folkets krav blev hörda. ${ }^{39}$ Hoten om nubisk secession förargade många av de nubiska aktivisterna som i åratal hade fått be- 
strida påståenden om just detta..$^{40}$ Katala-rörelsen tycks dock aldrig ha gjort allvar av sina varningar, och upplöstes kort tid därefter. 2013 försökte delar av den nubiska diasporan att lansera Det nubiska nilpartiet, som uteslutande skulle främja nubiska rättigheter. Trots att bildandet av ett sådant parti hade varit otänkbart under Mubarak, kan man förvånas över hur svalt intresset för ett enbart nubiskt parti var bland det nubiska folket efter revolutionen. För många var detta ett alltför radikalt steg att ta som riskerade att alienera det nubiska folket ytterligare, medan andra hade synpunkter på att initiativet kom från diasporen. Bland mina informanter påpekades också att nubier i Kairo hade andra behov än nubier i exempelvis Suezsåledes kunde inte allas behov täckas av endast ett parti. ${ }^{41}$ Följaktligen lyckades man inte få ihop ens de tusen underskrifter som behövdes för att kunna registrera Det nubiska nilpartiet som politiskt parti.

\section{Konstitutionella genombrott}

Efter massiva protester mot president Morsi drev den egyptiska armén juli 2013 bort ytterligare en president och upphävde landets konstitution. Detta åtföljdes av en ny konstitutionell process och antagandet av en ny konstitution i januari 2014. Den nya konstitutionen arbetades fram i två omgångar: 10-medlemskommittén och 50-medlemskommittén, som båda var tillsatta av interimpresidenten. För första gången var nubierna som grupp representerade i en konstitutionell process, och den tidigare fragmenterade nubiska rörelsen började nu samarbeta om utarbetandet av lagförslag. Inom ramen för 50-medlemskommittén ledde den välkända nubiska aktivisten och poeten Haggag Oddoul en nubisk arbetsgrupp. Även om Oddoul av många hade ansetts som alltför radikal bara få år tidigare, fungerande han nu som en förenande kraft bland aktivisterna, som bestod av en rad representanter från de olika föreningarna. Teamet slet dock med att väcka intresse för sina frågor - endast sex av kommitténs 50 medlemmar deltog i behandlingen av «den nubiska frågan».42 I slutändan fick dock det nubiska folket gehör för många av sina krav och från en nubisk ståndpunkt måste den nya konstitutionen ändå ses som en succé. För första gången någonsin omnämndes «Nubia» och ett nubiskt återvändande i en egyptisk konstitution.

Även om rätten att få återvända till fäderneslandet anses vara det överlägset viktigaste

\section{Många nubiska aktivister upplever än idag hotelser och förföljelse, och ibland även fysiska angrepp.}

kravet bland nubiska aktivister, blottade den konstitutionella processen de olika förståelserna inom den nubiska gruppen av vad ett nubiskt återvändande faktiskt borde innebära, och inte minst, vilka strategier som skulle användas gentemot den egyptiska staten för att få igenom detta krav. Som hos sociala rörelser på andra håll i världen ställdes de nubiska aktivisterna inte bara inför konkurrerande rättsliga tolkningsramar, utan också inför alternativa historiska och politiska tolkningsramar. ${ }^{43}$ När det gäller de förstnämnda länkar grupper såsom ECHR och NDYU det nubiska kravet om att återvända till gällande folkrättsliga regelverk, medan grupper som ENAL nästan uteslutande formulerar det med hjälp av det nationella regelverket. ENAL är varsamma med att «internationalisera» den nubiska frågan. Man menar att detta kan vara kontraproduktivt. Men även bland dem som grundade det nubiska återvändandet $i$ folkrätten, skiljer grupperna sig åt när det gäller vilka regelverk 
man anser mest lämpliga att åberopa. ECHR är ensam om att uttryckligen använda FN:s ramverk för urfolksrättigheter i sin mobilisering, och menar att ett erkännande av det nubiska folket som urfolk skulle innebära att den egyptiska staten tvingas att låta dessa återvända till sina traditionella landområden kring Nassersjön. Andra grupper, som den nyare Nubian Knights-gruppen väljer att använda det internationella ramverket gällande minoritetsrättigheter som grund för mobilisering för ett nubiskt återvändande. ${ }^{44}$ Jämförelsen med palestinierna har också gjorts, där vissa nubiska aktivister har menat att rätten att återvända inte bara är förbehållen palestinierna, utan också bör gälla det nubiska folket. ${ }^{45}$

Den tolkningsram som tycks vara mest utbredd och som också reflekteras i 2014 års konstitution, är historiskt och politiskt rotad i tvångsförflyttningen av det nubiska folket för mer än femtio år sedan. På 1960-talet motiverade dåvarande president Nasser tvångsförflyttningen just med behovet av "utveckling» och denna till synes neutrala term lyckades därmed avleda från känsliga sociala och politiska frågor. Många nubier ansåg «utveckling» därför vara en rättighet som följde av tvångsförflyttningen. Denna tolkningsram har blivit approprierad av många av dagens aktivister, som menar att rätten att återvända till fäderneslandet i hög grad också handlar om rätten till utveckling.

Tidigare studier visar hur mobiliseringsstrategier som erkänns som legitima av myndigheterna har större chans att lyckas, och detta tycks också vara tillfället här. ${ }^{46}$ Genom att åberopa tolkningsramen om "utveckling» lyckas nubiska aktivister länka sina egna krav till den tolkningsram som används av egyptiska myndigheter och därmed legitimera sitt krav om ett återvändande. Detta användande av ett till synes neutralt språk talar direkt till den egyp- tiska statens ovilja att erkänna det nubiska folket som urfolk eller minoritet. När nubiska aktivister i den konstitutionella processen krävde rätten att återvända till "Nubia» (området kring Nassersjön) och att bli konsulterade i alla frågor som berör utvecklingen av dessa landområden, är det således genom ramen för utveckling som aktivisterna lyckades få sina krav hörda. ${ }^{47}$ Följaktligen fastslår artikel 236 av 2014 års egyptiska konstitutionen att:

The State shall guarantee setting and implementing a plan for the comprehensive economic and urban development of border and underprivileged areas, including Upper Egypt, Sinai, Matrouh, and Nubia. This shall be made with the participation of the residents of these areas in these development projects, and they shall be given a priority in benefiting therefrom, taking into account the cultural and environmental patterns of the local community, within ten years from the date that this constitution comes into effect, as regulated by Law. The State shall work on setting and implementing projects to bring back the residents of Nubia to their original territories and develop such territories within ten years, as regulated by Law.

För de flesta nubier är artikel 236 en viktig milstolpe, medan andra fruktar att tolkningsramen om utveckling öppnar för en förståelse av den nubiska frågan som en fråga endast om egendom, istället för ett socialt, politiskt och ekonomiskt problem..$^{48}$ Vissa oroas också över att konstitutionen inte slår fast att ett återvändande är en nubisk rättighet. ENAL, vars egna lagförslag bygger på premissen att ett återvändande är en rättighet, är kritisk till konstitutionens koppling av nubiskt återvändande och nationell utveckling. Detta, menar man, tjänar statens intressen och ger nubiska folket rätt att återvända endast genom utvecklingsprojekt. Som Mounir Bashir har uttryckt det, nubier är inte "projekt» utan rättighetsinnehavare. 49 


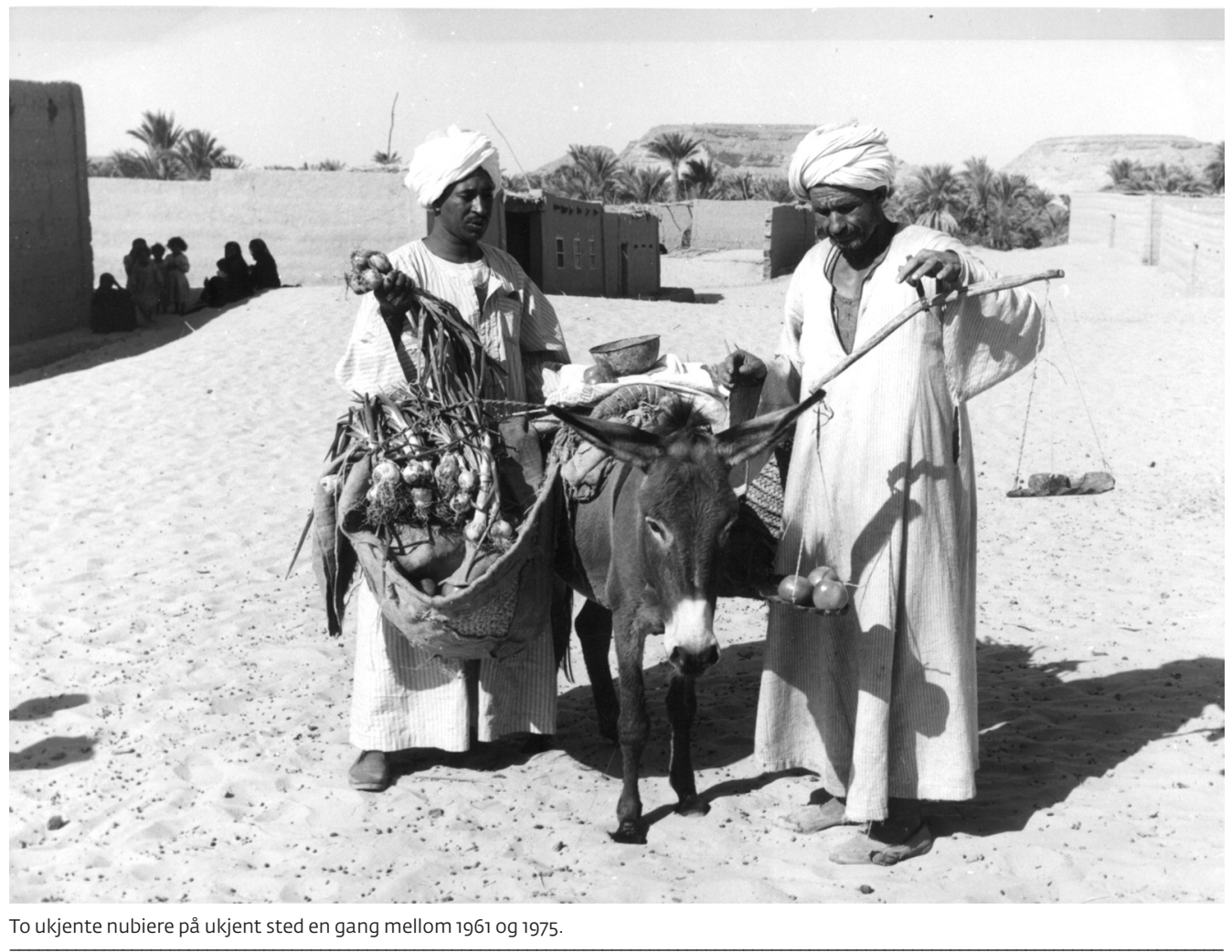

Som ett led i implementeringen av artikel 236 etablerade Ministeriet för övergångsrättvisa i september 2014 Kommittén för rehabilitering och rekonstruktion av Nubia. Den fick i uppgift att göra verklighet av artikel 236 genom att arbeta fram en särskild lag gällande nubiskt återvändande. ${ }^{50}$ I 25-mannakommittén återfinner vi åtta kända nubier eller nubiska jurister, bland dessa flera som tidigare var aktiva i Oddouls grupp under the konstitutionella arbetet. Representanter från Uppföljningskommittéerna och ENAL:s Mounir Bashir hade inte deltagit direkt i det konstitutionella arbetet men är nu nyckelpersoner; det är just ENAL:s tidigare lagförslag som har utgjort grundstommen för kommitténs tre hittills utarbetade lagförslag gällande «rehabilitering och utveckling av Nubia». Fortfarande slits kommitténs medlemmar av konkurrerande tolkningsramar, dvs. återvändande som en rättighet respektive återvändande som en fråga om national utveckling. I det senaste lagförslaget som skickades till minsterrådet för godkännande februari 2015 dominerar dock återigen det sistnämnda perspektivet.

\section{Dröm - rättighet - verklighet?}

I ett politiskt klimat där den egyptiska staten länge har kvävt all offentlig debatt om, eller mobilisering för, det nubiska folkets rättigheter är utvecklingen de senaste par åren inte annat än makalös. Denna artikel har visat hur nubiska aktivister alltsedan mitten av 2000talet har mobiliserat för förändring, men den rättsliga och politiska reformen framskyndades markant av 25-januari-revolutionen. Detta 
tycks ha kulminerat med omnämnandet av ett nubiskt återvändande i 2014 års egyptiska konstitution. Men kommer ett nubiskt återvändande till fäderneslandet att bli verklighet? Och om det gör det, när sker det och under vilka former? Det nubiska deltagandet i arbetet kring den senaste egyptiska konstitutionen lyckades mycket riktigt samla en tidigare fragmenterad rörelse, men fortfarande existerar konkurrerande tolkningsramar och förståelser av vad ett nubiskt återvändande faktiskt innebär. Detta tyder på att ett eventuellt återvändande kan bli en komplicerad process. Bland nubier finns också en rädsla relaterad till det våld som blossade upp i Assuan april 2014 mellan en arabisk och nubisk stam, och som lämnade fler än 30 människor döda och dussintals skadade. Egyptiska myndigheter reagerade långsamt och frustrerade nubier protesterade mot statens indolens. ${ }^{51}$ Juni 2014 blossade våldet upp igen, trots en vapenvila som medlades fram av stormuftin från Al-Azhar. Nubiska aktivister fruktar nya liknande händelser om de grundläggande orsakerna till våldet inte adresseras, däribland nubisk marginalisering.

Det senaste lagförslaget som är menat att implementera konstitutionens bestämmelser om ett nubiskt återvändande hotas inte bara av dessa konkurrerande tolkningsramar och det överhängande hotet om våldsamheter i Assuan. Nuvarande president Abdel Fattah elSisi, som valdes i maj 2014, har än mer militariserat det egyptiska samhället. Genom presidentdekret 444 har steg tagits som direkt underminerar arbetet i kommittén för rehabilitering och rekonstruktion av Nubia. Dekreten introducerades utan förvarning i november 2014 och innebär att stora områden kring Egyptens gränser etableras som militärzoner. I dessa områden återfinner vi 16 byar som kommittén har identifierat för nubiskt återvändande. Dekret 444 har överklagats av medlemmar av kommittén som menar att den strider mot den nya konstitutionen.

Slutligen har president el-Sisis säkerhetsstrategier också slagit hårt mot det egyptiska civilsamhället i stort. En rad nya restriktioner inskränker civilsamhällets aktörer, inte minst deras möjligheter att samarbeta med internationella aktörer. Denna oerhört prekära människorättssituation påverkar fler grupper än det nubiska folket; som en informant förklarade: "Alla i Egypten är förtryckta, inte bara nubierna, eller de kristna ... det gäller hela det

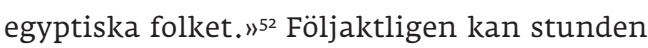
vara kommen för nubiska aktivister att återigen tvingas lägga om sina strategier.

\section{$\bullet f \bullet$}

1 Ali, Idris: Dongola: A Novel of Nubia. Fayetteville: University of Arkansas, 1998, i översättning av Peter Theroux. För en analys av detta verk, se även Abbas, Fatin: "Egypt, Arab Nationalism, and Nubian Diasporic Identity in Idris Ali's Dongola: A Novel of Nubia", i Research in African Literatures, vol. 45, nr. 3, 2014, s. 147-66.

2 Minority Rights: World Directory of Minorities and Indigenous Peoples, Nubians. 2011.

3 Poeschke, Roman: Nubians in Egypt and Sudan: Constraints and Coping Strategies. Saarbrücken: Saarbrücken Verlag für Entwicklungspolitik, 1996; Fahim, Hussein M.: Egyptian Nubians: Resettlement and years of coping. Salt Lake City: University of Utah Press, 1983.

4 Hughes, Emma: "Displacement and Indigenous Rights: the Nubian Case" i Venkateswar, Sita, och Hughes, Emma: Politics of Indigeneity. London: Zed Books, 2011.

5 Ett visst erkännande av religiösa minoriteter har dock funnits. Se Zuhur, Sherifa: "Claiming space for minorities in Egypt after the Arab Spring" i Ennaji, Mona (red.): Multiculturalism and Democracy in North Africa: Aftermath of the Arab Spring. New York, NY: Routledge, 2014.

6 Bernstein, Mary: "Cender, Queer Family Politics, and the Limits of Law”, i M. Bernstein, Mary, och Reimann, Renate (red.): Oueer families, Queer Politics: Challenging Culture and the State. New York: Columbia University Press, 2001; Bumiller, Kristen: The Civil Rights Society: The Social Construction of Victims. Baltimore: Johns Hopkins University Press, 1988; Burstein, Paul: "Legal Mobilization as a Social Movement Tactic: The Struggle for Equal Employment Opportunity”, American Journal of Sociology vol. 96, 1991, s. 1201-25.

7 Williams, Rhys: "The Cultural Contexts of Collective Action: Constraints, Opportunities and the Symbolic Life of Social Movements" i Snow, David A., Soule, Sarah Anne, och Kriesi, Hanspeter: The Blackwell Companion to Social Movements. Malden, Mass: Blackwell, 2004, ss. 93.

8 Lindgren, Johan och Wennerhag, Magnus: "Sociala rörelser, mångfald och enhet - en kommentar med nedslag i två sociala forum" Fronesis nr. 16-17, 2009, ss. 111-125. 
9 el-Mahdi, Rabab: "Enough! Egypt's Quest for Democracy", Comparative Political Studies, vol. 42, 2009, ss. 1011-1039.

10 Artikelförfattarens översättning.

11 Kymlicka, Will och Pföstl, Eva (red): Multiculturalism and Minority Rights in the Arab World. Oxford: Oxford University Press, 2014

12 ECHR: Individual NCO submission to the Office of the High Commissioner for Human Rights on the occasion of the seventh session of the Universal Periodic Review: Egypt. 2010. http://lib.ohchr. org/HRBodies/UPR/Documents/Session7/EG/ECHR UPR_EGY_So7_2010_EgyptianCenterforHousingRights.pdf (27.05.2015)

13 Allen, Samantha: Nubians and Development: 1960-2014. Middle East Studies Center, American University in Cairo, 2014; Mossallam, Alia: Hikayat Sha'b-Stories of Peoplehood, Nasserism, Popular Politics and Songs in Egypt 1956-1973. Department of Government, London School of Economics and Political Science, 2013

14 ECHR, 2010.

15 Abbas, 2014.

16 ECHR, 2010.

17 Tilly, Charles: From Mobilization to Revolution. Reading, Mass . Addison-Wesley Publishers, 1978.

18 ECHR, 2010.

19 Dersso, Solomon: Egypt: Constitutional, Legislative and Administrative Provisions Concerning Indigenous Peoples. Genève: ILO och African Commission on Human \& Peoples' Rights, 2009.

20 Dersso, 2009; Kymlicka and Pföstl 2014. En litterär nubisk rörelse som ofta omhandlar känsliga politiska teman har dock blomstrat de senaste decennierna. Se Abbas, 2014.

21 Khallaf, Rania: "Right of Return", i Al-Ahram Weekly, 2009 http://weekly.ahram.org.eg/2006/788/eg9.htm (27.05. 2015); Mahmoud, Saeid: "Nubian Author Seeks Pluralism in Egypt's New Constitution”, i Al-Monitor, 6. oktober 2013.

22 Nkrumah, Gamal: "No Benighted Nubia”, i Al-Ahram Weekly, 15. augusti 2013

23 el-Mahdi, 2009.

24 ECHR, 2010.

25 Intervju C, februari 2015. Alla intervjuer är konfidentiella.

26 Humanity in Action: Youth for Democracy: Learning from NonViolent Struggle across the World. Köpenhamn: Humanity in Action, 2012.

27 Intervjuer A, C och F, februari och mars 2015.

28 Intervju A, februari 2015.

29 Intervju C, februari 2015

30 Azer, Sherif: "Can the new Egyptian government deliver on the promise of the constitution to the Nubian people?", Frontline Defenders. http://www. frontlinedefenders.org/ node/25624\#sthash.blKNsWkM.jFNROgBf.dpuf (27.05. 2015).

31 Nkrumah, 2013.

32 al-Agamy, Ibrahim: "An Unrecognized Majority”, Corre- spondents.org, 15. januari 2013. http://www.correspon dents.org/node/1650 (27.05 2015).

33 Gehad, Reem: "Nubians still dream of return to historical lands in Upper Egypt”, i Ahram, 20. januari 2013. http://english.ahram.org.eg/NewsContent/1/64/ 62861/Egypt/Politics-/Nubians-still-dream-of-return-tohistorical-lands-.aspx (27.05.2015).

34 Intervju D, februari 2015.

35 el-Tibi, Manal och Jadaliyya: "Resignation Letter to Egypt's Constituent Assembly", i Jadaliyya Reports, 12. oktober 2012. http://www.jadaliyya.com/pages/index/7777/textof-manal-el-tibis-resignation-letter-to-egypt (27.05.2015).

36 Nkrumah, 2013.

37 Emam, Fatma: “The Nubian Challenge", i The Egypt Monocle, 17. juli 2012.

38 Kortam, Hend: "Nubians protest marginalization", i Daily News Egypt, 20. januari 2013

39 Hamed, Enas: "Will Nubian demands for return become calls for secession?”, i Egypt Pulse, 25. november 2014. http://www.al-monitor.com/pulse/originals/2014/ 11/nubia-egypt-displacement-right-return-secession.html \#ixzz3TQqoY9oo (27.05.2015); al-Agamy, 2013.

40 Intervjuer $\mathrm{A}$ och $\mathrm{B}$, februari 2015.

41 Intervju A, februari 2015.

42 Emam, Fatma: "Being Nubian in Egypt, and in the constitution”, i MadaMasr, 23. december 2013.

43 Pedriana, 2006; Marshall, Anna-Maria: Confronting Sexual Harassment: The Law and Politics of Everyday Life. Burlington: Ashgate, 2005.

44 Nubian Knights: "Know Your Rights Ya Noby Number Three," Nubian Knights Facebook-sida, 11. juni 2014. https://www.facebook.com/nubianknightsteam/posts/ 716253208434446 (27.05.2015).

45 Megahed, Mohamed M.: "The Right to Return is Not Only Palestinian", Nubian Youth Democratic Union, 23. april 2013. http://www.y4nubia.blogspot.com/2012/o4/blogpost_23.html (27.05.2015).

46 Adam, Barry D, m fl.: "Gay and Lesbian Movements Beyond Borders? National Imprints of a Worldwide Movement", i Adam, Barry D. Duyvendak, Jan W., och Krouwel, Andre (red.): The Global Emergence of Cay and Lesbian Politics Philadelphia: Temple Univ. Press, 1999; Chua, Lynette J.: "Pragmatic Resistance, Law and Social Movements in Authoritarian States: The Case of Gay Collective Action in Singapore", Law \& Society Review, vol. 46, ss. 713-48.

47 Emam, 2013

48 Intervjuer B och D, februari 2015.

49 Allen, 2014.

50 Ahram Online: "Egypt forms committee to draft law for Nubian resettlement”, 8. oktober 2014. http://english. ahram.org.eg/NewsContent/1/64/112628/Egypt/Politics/Egypt-forms-committee-to-draft-law-for-Nubianrese.aspx (27.05.2015).

51 Aman, Ayah: "Egypt's Nubians demand rights on Aswan High Dam anniversary”, i Al-Monitor, 9. juni 2014.

52 Intervju F, mars 2015. 